\title{
BÚVÁRKODÁS A TERMÉSZETTUDOMÁNYOKBAN. VIDÉKI GYEREKEGYETEM NYÁRI TÁBOR A PEN-EN
}

\author{
TOURING NATURAL SCIENCES \\ RURAL CHILDREN'S SUMMER CAMP AT PEN
}

\author{
Gerencsérné Berta Renáta', Barabás Enikő2 , Bíró Ildikó3 ${ }^{3}$ Pozsgai Emília" ${ }^{4}$ Nagy-Péterfi Rita ${ }^{5}$, \\ Galambos Ildikó ${ }^{6}$ \\ 'PhD, tudományos munkatárs*, berta.@@sooswrc.hu \\ tudományos segédmunkatárs* \\ ${ }^{3} \mathrm{PhD}$, tudományos munkatárs* \\ 4PhD, tudományos munkatárs* \\ `ügyvivő szakértő, Pannon Egyetem Nagykanizsai Kampusz \\ ${ }^{6} \mathrm{PhD}$, tudományos fömunkatárs* \\ *Pannon Egyetem Mérnöki Kar Soós Ernő Víztechnológiai Kutató-Fejlesztő Központ, Nagykanizsa
}

\section{ÖSSZEFOGLALÁS}

A gyermekek természettudományi érdeklődésének felkeltésére, illetve fokozására a nagykanizsai Soós Ernő Víztechnológiai Kutató-Fejlesztő Központ Gyerekegyetem Nyári Tábor elnevezéssel indított útjára egy tehetséggondozó programsorozatot az általános iskolás korosztály számára. A nyári tábor során a gyerekek egy héten keresztül tematikus napokon vettek részt, ahol kémiai, biológiai kísérleteket próbáltak ki, a természetben barangolva ismerték meg környezetük élővilágát, betekintést nyertek az ásvány- és gyógyvizek világába, valamint megismerkedtek a fenntartható fejlődés fogalmával. A tábor a tehetséggondozás egy kezdeti lépése, melyet a jövőben további foglalkozásokkal, szakkörökkel, előadássorozatokkal kívánnak bővíteni a kutatóközpont kollégái.

\section{ABSTRACT}

To raise and enhance the interest for natural sciences in children, Ernő Soós Water Technology Research and Development Center in Nagykanizsa, southwestern Hungary started a talent management program called Children's Summer Camp series for elementary students. For a week children participated in programs during a series of thematic days where they experimented with chemical and biological tests, exploring the wildlife of their environment and the natural world, gaining insight into the world of mineral and medicinal water and the concept of sustainable development. The camp is an initial step of the talent management, which will be expanded by colleagues from the Research Center in the future with further occupations, skills and series of lectures.

Kulcsszavak: tehetséggondozás, gyerekegyetem, nyári tábor, természettudományok

Keywords: talent promotion, children's university, summer camp, natural sciences 
A Gyerekegyetem Nyári Tábor rendezvényt 2017 nyarán indította útjára a Pannon Egyetem Mérnöki Karán 2014 szeptemberében létrehozott Soós Ernő Víztechnológiai Kutató-Fejlesztő Központ a nagykanizsai telephelyen. Célja a nyári táborral az volt, hogy a vidéki gyerekek számára a biológia, kémia, fizika, földrajz, víztechnológia területein minél többet mutathasson. A tudományok fontosságát, sokszínüségét, a kutatói élet szépségét érzékeltették mindezzel. A Gyerekegyetem Nyári Tábor a szokványostól eltérően, napközis tábor formájában került megrendezésre. A célcsoport az általános iskolai (7-12 év) korosztály tagjai voltak Nagykanizsáról és a vonzáskörzetéből.

A nemrégiben alakult kutatóközpont több tudománynépszerüsítő rendezvényen vett részt, úgy mint a Kutatók Éjszakája, Szakmák Éjszakája. A központ Nyílt Laboratóriumot müködtet, mely lehetőséget teremt a tanulóknak a mindennapi kutatómunkába való betekintéshez, illetve maguk is részesei lehetnek a munkának, saját kísérleteket végezhetnek.

A Gyerekegyetem Nyári Tábor során a gyerekek egy héten keresztül tematikus napoknak lehettek részesei. Különböző előadások, bemutató kísérletek és saját maguk által elvégezhető kísérletek segítségével jutottak közelebb a tudományokhoz, továbbá alkalmi foglalkozásokon, kiránduláson vehettek részt (1. kép). A tábor végén pedig esküvel erősítették meg a „kis tudósok” a tudományos élethez való kötődésüket.

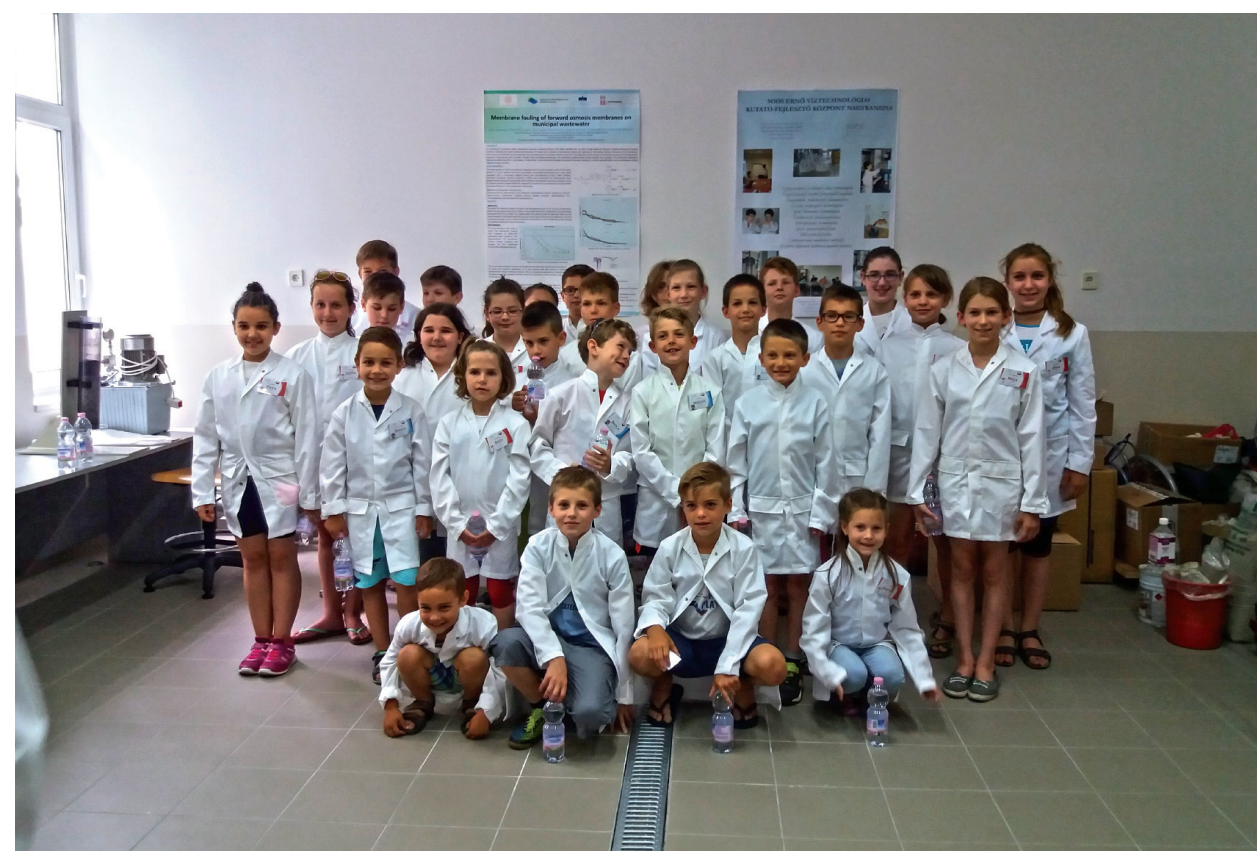

1. kép. Az első turnus résztvevői a Gyerekegyetem Nyári Táboron 
A Pannon Egyetem hírnevét öregbítve a Gyerekegyetem Nyári Tábor már az általános iskolás korosztállyal is meg kívánta ismertetni a tudomány világát. A tábor résztvevői tizenöt-húsz fös csoportokba szerveződve vettek részt a foglalkozásokon. Az érkezés után a napok egyszerü testmozgással kezdődtek, majd Kutakodó foglalkozásokkal folytatódtak. A tábor fő témája a víz, a mindennapi életünk lételeme, mely nélkülözhetetlen mindenki számára, különösen a tiszta víz.

Az első, a Földrajz napján a víz történeti áttekintésén túl a gyerekek megismerkedhettek a különböző víztípusokkal, megkóstolhattak különbözö eredetủ ásvány- és gyógyvizeket, természetesen a számukra megengedett mennyiséget nem túllépve. Különböző földtörténeti korokból származó kőze-

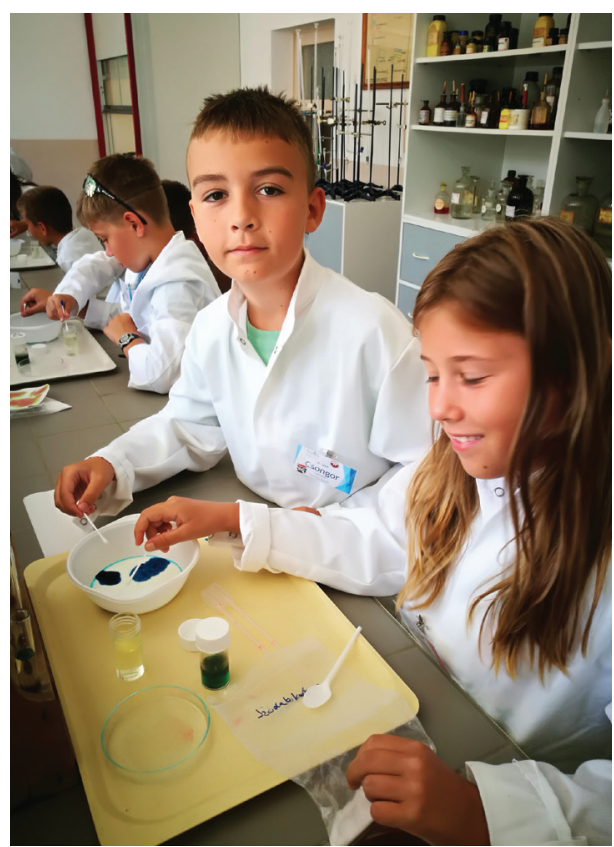

2. kép. Kémiai kísérletek teket és azokhoz kapcsolódó csiszolási technikákat ismerhettek meg, míg a tábor résztvevőinek a délutáni program kvízjátékkal és csillagdai látogatással telt.

A második, a Kémia napján a Kutakodó keretében a gyerekeknek volt lehetőségük önállóan végezni különböző „konyhai” kísérleteket, megismerkedhettek néhány kémiai folyamattal. Bár nagyon hiányoztak számukra a hanggal járó kísérletek (a robbanások), nagy érdeklődéssel figyelték az előadó által bemutatott tanári kísérleteket, és érdeklődő kérdéseket tettek fel a témával kapcsolatban. Azonban a következő foglalkozáson a hanghatású kísérletek sem maradtak el, ahol tüzzel kapcsolatos bemutató kísérletekben volt részük (3. kép). Megismerkedhettek a mikroszkópos biológia szépségeivel, ahol különböző típusú vizekben fellelhető élőlények mozgását és előfordulását figyelhették meg. A fárasztó Kutakodó foglalkozások után a gyerekek kipihenhették magukat egy, a témához kapcsolódó mozifilm megtekintésével.

A harmadik nap a Technológia napja volt, melynek keretében különböző, a víztisztításban használt berendezésekkel, technológiákkal ismerkedhettek meg a résztvevők (4. kép). Betekintést nyertek a kutatás során használt hagyományos és membrános technológiákba, valamint a közelben található használt víz tisztítását maguk is elvégezhették egy multimédia szürő segítségével. A délutáni csapatvetélkedők kovácsolták és építették a csapatokat a kiránduláshoz és a további napokhoz. 


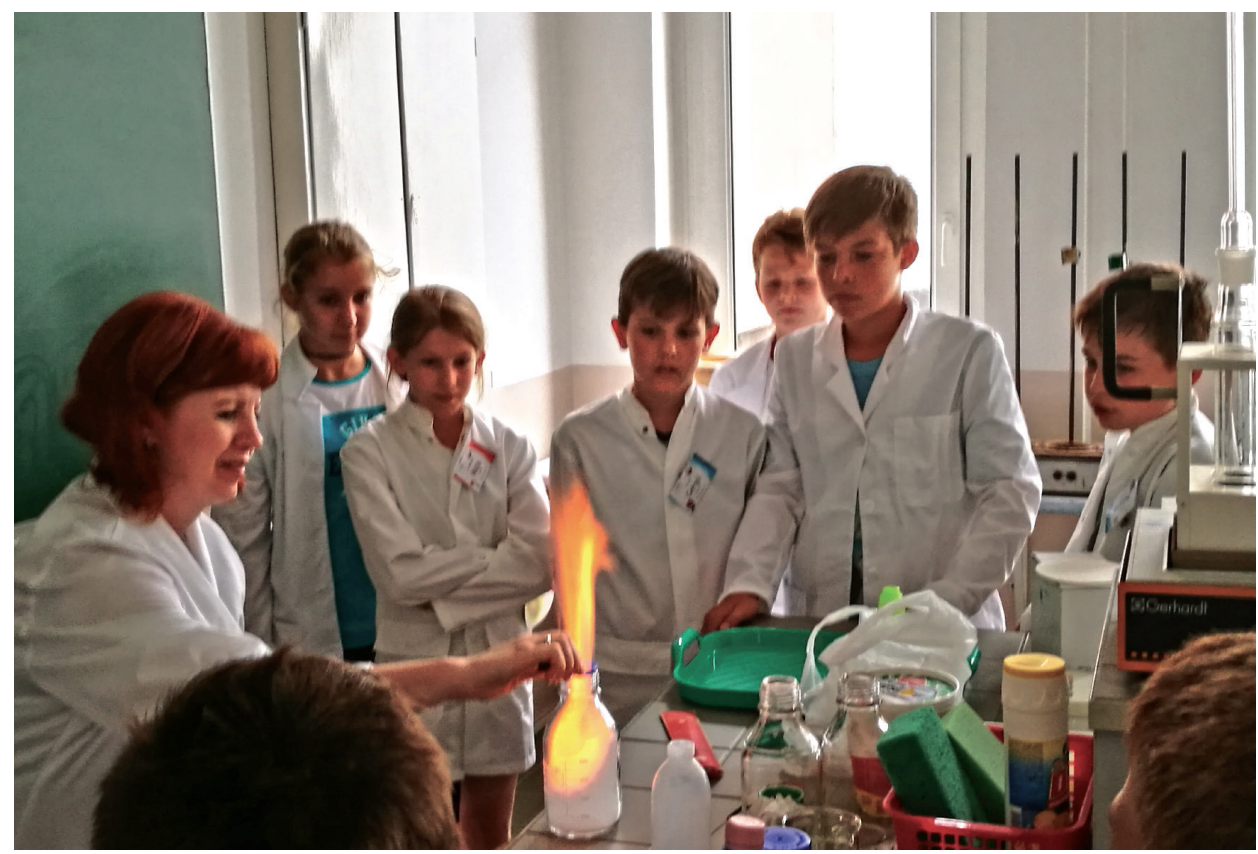

3. kép. A fütyülő palack kísérleti bemutatása

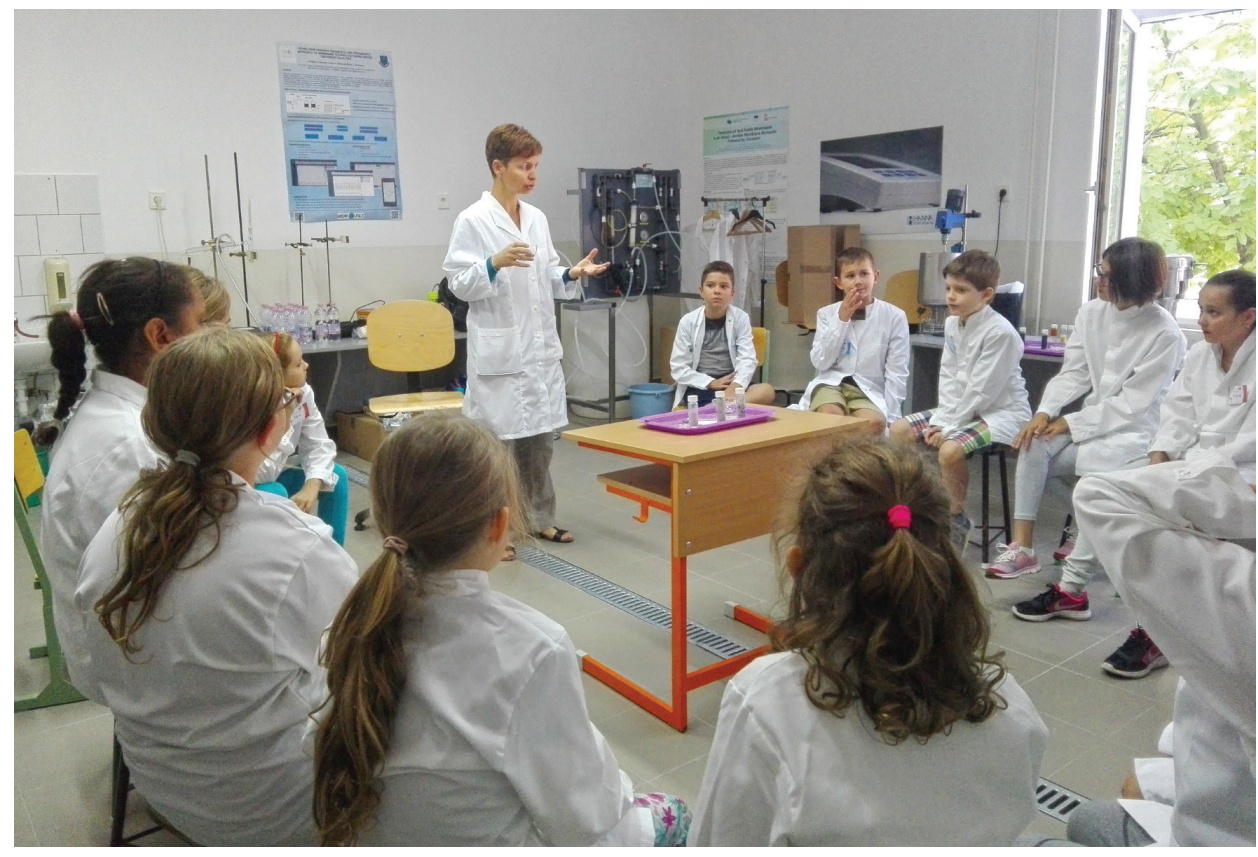

4. kép. A víztisztításban alkalmazott technológiák ismertetése 
A negyedik (Biológia napja) és az ötödik nap (Zöld nap) a természetben és a környezettudatosság jegyében zajlott, ugyanis a negyedik napon került sor a közeli tó élővilágának és az ott található éloolényeknek a megismerésére, valamint erdei kirándulásra $(5$. kép). A délután folyamán előkészületek zajlottak egy Környezettudatos nevelés címü videó elkészítéséhez, melynek bemutatására a záró napon került sor. Az utolsó napon a társadalmi felelősségvállalásról hallhattak ismertetőt a résztvevők, illetve ezzel kapcsolatos kvízjátékok zajlottak. A délutáni gyereknap (ugráló, vízibomba, szökőkút), családi piknik alkalmával pedig sor került a „kis tudós” avatásra, az oklevelek és az úti csomagok átadására.

A tábor finanszírozását segítette a

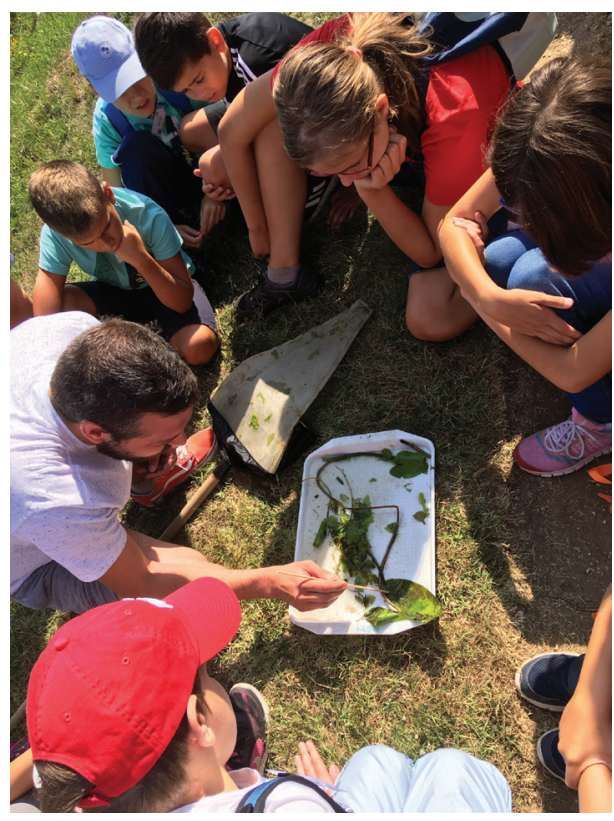

5. kép. A vízi élővilág tanulmányozása szabad szemmel szülők befizetésén túl az egyetem mellett müködő Kanizsa Felsőoktatásáért Alapítvány, valamint a Nagykanizsai Kampusz kollégái. A laboratóriumi munkához a hallgatói laboratóriumokat a Nagykanizsai Szakképzési Centrum biztosította. A helyi kis-, közép- és nagyvállalatok, a városi vezetőség támogatása és segítsége is hozzájárult a tábor sikeréhez.

A kéthetes turnusban közel száz vidéki gyermek vett részt anélkül, hogy a tábort reklámozták volna. A feladatok kivitelezésében, az előkészítő munkálatokban húsz kolléga segítette a munkát. A foglalkozások, kísérletek megtartása az előadón kívül több dolgozó és hallgató segítségét igényelte.

A Gyerekegyetem Nyári Tábor az oktatóknak és a programban részt vevő segítő kollégáknak igazi kihívás volt, hisz a megszokott egyetemi korosztályhoz képest teljesen más életkorú hallgatókkal kerültek kapcsolatba, ami új módszereket igényelt. Nagyobb felelősség hárult rájuk, a tudományos magyarázatokat a kisgyerekek nyelvén kellett elmagyarázni, ami szintén kihívást jelentett a számukra.

A tábor végén a gyermekek és a szülők megelégedésére, pozitív visszajelzések sorozatára alapozva, a nagy érdeklődésre való tekintettel a szervezők úgy döntöttek, hogy a tábort a következő években is megszervezik, melyet előregisztrációval el is indítanak. A szülői vélemények közül egyet kiragadva: „Kedves Szervezők, Oktatók és Mindenki, aki részt vett a tábor kivitelezésében! A Gyermekeim nevében is szeretném megköszönni ezt az élményekben gazdag, szuper hetet! Már most tervezik a jövő évi részvételt!" 
A természettudományos érdeklődés kibontakozására elindítanak továbbá egy év közbeni tudományos sorozatot Vidéki Mindentudás Egyeteme címmel, melyet kibővítenek a középiskolás és felnőtt korosztályra is. Az egyetemi életre való felkészüléshez pedig egy felkészítő kurzus keretében adnak lehetőséget a kémia, biológia és informatika szakterületein.

Összefoglalva: A Gyerekegyetem Nyári Tábor egy élményekkel teli programsorozat az általános iskolás tanulók számára, akikből a jövő tudósai kerülhetnek ki. Nemcsak a férőhelyek azonnali betöltése, hanem a pozitív visszajelzések is arra engednek következtetni, hogy hasonló rendezvényekre igenis nagy igény van hazánkban. A tapasztalatok alapján néhány apró módosításon kívül lényegi változtatás, átalakítás nem szükséges, a tábor tematikája megállja helyét a tudományos életre való felkészítésben. A szervezők büszkék arra, hogy a felnövekvő generáció számára élményekben gazdag programot nyújthattak.

Köszönetüket fejezik ki a Pannon Egyetem Mérnöki Kara vezetőségének, a Nagykanizsai Kampusz kollektívájának, a Nagykanizsai Megyei Jogú Város vezetőségének, a Kanizsa Felsőoktatásáért Alapítványnak, a Nagykanizsa Szakképzési Centrumnak, valamint a Netta Pannoniának, az Íz Birodalomnak és a támogató kis-, közép- és nagyvállalatoknak. A dolgozók, hallgatók és kedves munkatársak önzetlen és odaadó munkáját is dicséret illeti. 